\title{
Generational Differences Related to Linguistic and Discourse Features of WhatsApp Users of Texting
}

\author{
W C Perdhani ${ }^{1}$ R Roni ${ }^{2}$ \\ ${ }^{1}$ Universitas Brawijaya Malang, \\ ${ }^{2}$ Universitas Tridinanti Palembang
}

\{caterine_widya@ub.ac.id $\left.{ }^{1}\right\}$

\begin{abstract}
The aim of this study is twofold: 1) to find out what aspects of linguistic and discourse features are contained in WhatsApp conversations 2) to investigate WhatsApp used by different generations. WhatsApp analysis tertiary level students, Indonesia was conducted to analyse the language elements used in WhatsApp groups. WhatsApp chat collected through mobile devices is fully analysed and then categorized into linguistic and discourse features. The results shown in this study are that there are several differences between the WhatsApp language used by generation $\mathrm{X}$ and generation $\mathrm{Y}$ in linguistic and discourse features. WhatsApp's message to Generation $\mathrm{X}$ is more likely to use letters that are omitted, logograms, and initialism, while Generation Y uses non-standard spelling, shortening, and pictograms. The features of discourse in both generations produce the same number of mixed languages. Whereas generation $\mathrm{Y}$ uses fewer letters for emphasis in conversation while they using WhatsApp than generation $\mathrm{X}$.
\end{abstract}

Keywords: WhatsApp, Gender-Based Differences, Multilingual, Linguistic Aspects

\section{INTRODUCTION}

In the Twenty-First Century, the global importance of using WhatsApp has been increasing through the use of the internet. WhatsApp is a texting application that uses the internet to send and receive content, pictures, videos, sound, and media messages to a user's mobile phone [1]. In addition, WhatsApp is a free application, easy for everybody to use, and personal setting for private or group communication. It is an easy gadget to used by group or private communications [2]. Most importantly, it can be seen as a social network that enables individuals to get to a lot of information quickly. Therefore, it offers a unique opportunity to study how it may affect the use of language of its users.

In an analysis of generational differences, [3] found that they can be divided into four types: Traditionalist, Baby-boomer, Generation X, and Generation Y. Traditionalist consists of individuals born before 1946. Traditionalists are the oldest group and are in retirement. Baby-boomers consists of individuals born between 1946 until 1946. Baby-boomers are biggest in number, impact, and scope. The Boomers, as they are often known, continue to have a great influence all areas of society. Generation $\mathrm{X}$ are groups of individuals that born 
between 1965 and 1980. Thus this generation is the smallest number and is perceived as having a lack of a social identity. Generation Y consists of individuals born between 1981 until 2000. This generation tend to be technologically advanced and eager to learn.

Using the categories outlined above, the participants in this study were users of WhatsApp from Generation $\mathrm{X}$ and Generation $\mathrm{Y}$, as it was felt that they have experienced events and formed their world view through rapid technological advancement and globalization. In addition, it was felt that there may well be generational differences, also known as generation gaps which show themselves in the way they use language when texting.

Based on the background above, this research seeks to focus on the development or change of language use through an analysis of the discourse and linguistic features across generations $\mathrm{X}$ and $\mathrm{Y}$ in Indonesian context, within the highly interactive and rapidly change environment of those using texting on the WhatsApp.

Numerous studies have attempted to explain generational differences, linguistic and discourse features in communication tools. The scope of this study is focused on generational differences related to linguistic and discourse features. Past research sought to examine linguistic and discourse features in male and female language in SMS. In line with more recent studies, thus study focuses on the use and generational differences related to linguistic and discourse features of WhatsApp. A popular and more current communication application.

According to [4], there is a noticeable difference between the language of SMS text messages sent by men and women in Iran. The results of their study showed that Iranian women made complex sentences, used formal openings, closings, expressions of thought, feelings, and emotions in their texting. It was describing as a much higher level than men who created simple, short and strictly to the point texts.

Later in 2016, [5] found that female university students used various linguistic and discourse features in their use of SMS. The study focused on text messages from female students' in the $20-23$ age range. The study was also limited to certain language aspects. Culture and belief used in communication as a symbols which were unavailable on their device or gadget to show a mutual relationship, and t express their emotions and actions. The main limitation of this study is that it only focused on female students in the age range of $20-23$. Thus, different results may be found when collecting data from other groups from age ranges, background or gender.

Following an extensive search, it was only possible to find no studies on linguistic and discourse features that sought to explain generational differences. Therefore, this studies aims to fill that gap and investigate the linguistic and discourse features in a WhatsApp group created by doctoral degree students in the Indonesian context. As a result, the following research questions are addressed in the present study:

- What are the linguistic and discourse features of WhatsApp messenger language created by Generation X and Generation Y?

- What are the generational differences found in linguistic and discourse features created by Generation $\mathrm{X}$ and Generation $\mathrm{Y}$ ?

\section{RESEARCH METHOD}

We collected WhatsApp messages that were written from 10 doctoral degree students (ages 28-50) who are majoring English in the Graduate Program, Universitas Negeri Malang, Indonesia. We selected the data from WhatsApp group namely "Stronger Together" based on their consent form and availability of corpus data. To obtain data for this study, WhatsApp group of doctoral students who were preparing themselves for the dissertation examination 
process, then, collected their conversations to be selected based on linguistic and discoursal features. Subject 10 in number: 6 male and 4 female. Their age ranges from 28 to 50 years.

In February 2018 the doctoral degree students of Graduate Program, Universitas Negeri Malang, Indonesia created a WhatsApp group name "Stronger Together". Group recruitment is not forced, and members can maintain groups if they feel useful or leave the group if they do not want to stay. Members used different smartphones, and WhatsApp Messenger for Android was used updated by February 2018. Languages used for messaging were Indonesian, Javanese and English as preferred by Users (fig.1)

We manage to collect 4.109 posts. We had employed discourse analysis to analyse the linguistics and discoursal features in the texts. This methodology is reasonable since "the talk of content informing is formed as much by individuals' attention to whom they are messaging and how they need to run over" (Tagg 2012, p. 3). This implies messaging likewise has talk markers of facial pictures framed using joined accentuation images that unequivocally demonstrate individuals' mentalities and emotions, for example, those found in talking styles. The information was then examined and arranged into the classes of phonetic and discoursal highlights of SMS by Crystal (2008) Heidari and Alibabaee (2013) and ) and Yusuf et al [7]. In the parts of phonetic highlights, we alluded to Crystal's (2008) and [7] characteristics; they are logogram, pictogram, overlooked letters, nonstandard spelling, initialism, shortening, and certifiable oddities. In the wake of dissecting the measures of semantic highlights by Qualitative Data Analysis Software, we utilized an unassuming factual equation to change over the recurrence of sum into a type of a rate.

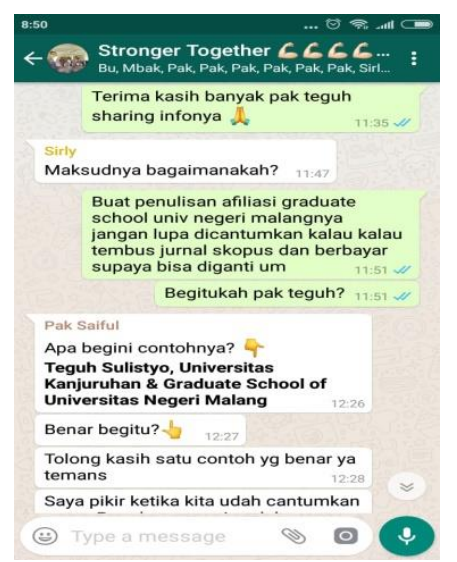

Figure 1. Example of one of the conversations

\section{RESULTS AND DISCUSSION}

In the form of linguistic features, the frequency and percentage for each feature are presented in Table 1 and table 2. 
Table 1. The frequency and percentage of the linguistic features in WhatsApp messenger

\begin{tabular}{lcccc}
\hline & \multicolumn{2}{c}{ Generation X } & \multicolumn{2}{c}{ Generation Y } \\
\cline { 2 - 5 } Linguistic Features & Frequency & Percentage & Frequency & Percentage \\
\hline Logogram & 190 & 19.8 & 52 & 7.9 \\
Initailism & 151 & 15.7 & 63 & 9.6 \\
Omitted Letters & 392 & 40.9 & 92 & 14 \\
Shortening & 135 & 14.1 & 143 & 21.8 \\
Non-standard spelling & 18 & 1.9 & 187 & 28.5 \\
Pictogram & 73 & 7.6 & 120 & 18.3 \\
Genuine Novelties & 0 & 0 & 0 & 0 \\
Total & 959 & 100 & 657 & 100 \\
\hline
\end{tabular}

As it can be seen from table 1, that genuine novelties have never been used in WhatsApp conversation both in Generation X and Generation Y. In the collected data generation X and generation $\mathrm{Y}$ used zero cases of genuine novelties.

\subsection{Logogram}

The feature of logogram emotions is using signs to express meaning. Logograms are represented features which from single letters, numerals and typographic symbols became words, parts of words or even associated words with actions. These kind texters reveal are popular on generation X than generation Y. In our data, generation X used 190 cases (19.8\%) and generation $\mathrm{Y}$ used 52 cases $(7.9 \%)$ of logogram in their messages. Following data show some our examples:

1) a. "Ttp semangat buat tmn2 yg akan menuju kelayakan selanjutx."(Generation X)

b. "Keep spirit for friends who are going to kelayakan examination for next."

c. (Keep spirit guys for who are going to kelayakan examination.)

2) a. "hmhmhmhm Mengingat besok pak dani ujian,besok rencana qt kasih surprise a kali bagaimanakah"(Generation Y)

b. "(mumbling) Remember tomorrow is Mr. Dani examination, tomorrow our plan gives surprise Mr. Ali, how?"

c. (mumbling) Don't forget tomorrow is Mr. Dani examination!Our plan give a surprise to Mr. Ali tomorrow, how about that?)

From the data analysis, we found selanjutx for next and hmhmhmhm for mumble as the most frequently used forms in the data. Generation $\mathrm{X}$ often produces $x$ for the next and possessive pronoun in their WhatsApp conversation. Data 2 that produced by generation $\mathrm{Y}$ used some form of mumble such as hmhmhhm for opening and sometimes to make sense of a statement. The finding is in line with [7] which states that logogram was to condense words. By using a logogram, it can be concluded that both generations (Gen-X and Gen-Y) want to convey the same message as when they delivered it when communicating face to face. Thus, the written text such as: selanjutx and hmhmhmhm of logograms is considered as orthographically speaking of daily conversation [8].

\subsection{Initialism}

Words are reduced to their initial letters. Initialism contributes when some words are reduced into their initial letters. In our data, it revealed that generation $\mathrm{X}$ is use more often initialism than generation $\mathrm{Y}$. The results showed that generation $\mathrm{X}$ contributes 151 cases 
(25.7\%) while generation $\mathrm{Y}$ was 63 cases $(9.6 \%)$. Here, the following examples of initalisms data:

1) a. "BTW Take ur time Bund..." (Generation X)

b. "By The Way take your time, Ma'am!"

c. (Please take your time, Ma'am!)

2) a. "Siap menunggu BF dg empek2... pesan duluan nih"( Generation Y)

b. "Ready waiting to break fasting with pempek - pempek... order first!)

c. (We are waiting to break fasting with pempek - pempek Please make an order!)

From the data above, initialism indicated that the texters tended to employ this feature in English instead of bahasa Indonesia. Data 1 and data 2 for initialism showed in English. This was due to the background of the texter as a doctoral degree student in English and Education. [9] had conducted similar research that their research is focused on initialism. In line, the data of this study is represented simplified intialisms which the elements on conversation in mix or half part of the lexical.

\subsection{Omitted Letters}

Omitted letters in our data are much more used in among generation $\mathrm{X}$. They represent as 392 cases $(40.9 \%)$, while the generation Y only are 92 cases $(14 \%)$. These following data are representing example omitted letters:

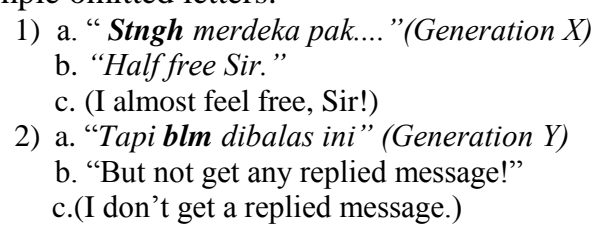

The data shows that most forms of omitted letters involved the omission of vowels (i.e. stngh for setengah (half), blm for belum (not yet),klr for kelar ( finished)). The generation $\mathrm{X}$ $(40.9 \%)$ tend to produce more omitted letters than Generation Y (14\%). This happened because they tried to condense the words in their WhatsApp message in order to fit their messages to the space available. This omitting is frequently used in message text. As the result, it is lead to creative lexical reductions in terms to save time, space and effort [10].

\subsection{Shortening}

The user eliminates or omits an important part of words. Shortening have happen when some letters are getting deletion in a word. These shortening letters are represented among generation $\mathrm{Y}$. In this data, it revealed that generation $\mathrm{Y}$ has 143 cases $(21.8 \%)$ while generation $\mathrm{X}$ represents 135 cases $(14.1 \%)$. Here, the following are example data:

1) a. "kalau dibutuhkan siapppp Capt" (Generation X)

b. "ready, Capt!"

c. (we come immediately, Captain!)

2) a."Perpus pasca" (Generation Y)

b. "library pascasarjana"

c. (I am at library pascasarjana.)

All the data above showed common shortening which are known in the same background knowledge among the doctoral students in their academic life. Therefore, no confusion would occur between them. The shortenings are such as Capt for Captain, Perpus for Perpustakaan (library) and pasca for pascasarjana for (Graduate School). Others found in data were Bro for 
Brother and Sept for September. Other shortened names of the month were also often found in the students' daily communication. [11] also supported similar cases that teenagers communication is very common to do shortening in terms of text messaging.

\subsection{Non-Standard Spelling}

Words which are manipulated by texters.

1) a. "Palagi sy blg good news dr mas Dani n beliau jg sdh ksh feedback artikel sy". (Generation X)

b. "Palagi, I've told good news, bro, Dani, and he hasn't received any feedback".

c. (Moreover, I told (him) about the good news from Dani, and he also gave feedback on (my) article)

2) a. "Mantabss pak dani". (Generation Y)

b. "Great sir Dani"

c. (Great Job Mr. Dani)

We found some several different forms of non-standard spelling as shown in the corpus data above which modifications were based on the word's pronunciation and the WhatsApp texter's style. Generation Y tend to use more on non-standard spelling than Generation X. When non-standard spelling arouse between messaging text, [12] thought it might be violated of phonological awareness. Moreover, their result in adult case is no effect since they already developed in reading literacy.

\subsection{Pictogram}

The use of visual shapes or pictures to represent objects or concepts.

1) a. "(-):-0 dokter koplak. Perlu kuliah pragmatics". (Generation X)

b. "(-):-) koplak doctor. Need to study pragmatics"

c. (-) (-):( smilling face with the open mouth) stupid doctor. Need to get pragmatics lectures)

2) a. "Hahaha iya mbak pipit pokoknya $\square \square \square \square$ ganbate" (Generation Y)

b. "Hahaha, pipit, the important thing is to keep it up $\square \square \square \square$ "

c. ( Haahaha (foolish laugh), (the most) important thing is still trying to be passionate $\square \square \square \square($ muscle))

From the information above, every sort of pictogram is made to speak to different feelings. We further perceive that the texters' way of life and conviction likewise assumed a critical job for imaginatively making more images that are not accessible in the cell phone's application to express more feelings and activities. The signs of emoticons are also representative between supplementing verbal content and also semantic properties of sentence structure [13].

Pictogram, or in short is emoticon, certainly uses by woman and young age people to show their nonverbal cues [14]

\subsection{Genuine Novelties}

Based on the data comprises that the genuine novelties in Generation $\mathrm{X}$ and Generation $\mathrm{Y}$ didn't show the occurrences. The second part of the results of this study comprises the analysis of using discourse features as mixed language and capital letters for emphasis on the content of the text messages created by Generation X and Generation Y. The obtained results are shown in the following table (Table 2) 
Table 2. The frequency and percentage of the discourse features in WhatsApp

\begin{tabular}{lcccc}
\hline & \multicolumn{3}{c}{ messenger } \\
\cline { 2 - 5 } & \multicolumn{2}{c}{ Generation X } & Generation Y \\
\cline { 2 - 5 } Mrequency & Percentage & Frequency & Percentage \\
\hline Capital letters for emphasis & 908 & 95.3 & 572 & 99.5 \\
Total & 45 & 4.7 & 3 & 0.5 \\
\hline \hline
\end{tabular}

\subsection{Mixed Language}

Mixed words have happened in a text when the message has contained several languages. In this data, the generations $\mathrm{Y}$ are recently used mixed words. The percentage of generations $\mathrm{Y}$ showed $99.5 \%$ (572 cases), while generations X collected $95.3 \%$ (908 cases). These following are example data:
1) a. "Kami skr otw FS"(Generation X)
b. "we're now on the way FS"
c. (We are heading to Fakultas Sastra)
2) a. "Y ditunggu sj nggih" (Generation $Y$ )
b. "Yes, just wait there"
c. ( Yes, we are just waiting yeah)

From the 572 cases or $99.5 \%$ occurrences in Generation $\mathrm{X}$, there were 6 different languages recorded by the researcher. The sixth languages were Indonesian, English, Arabic, Javanese and Sundanese.

From the 908 cases or $99.3 \%$ occurrences in Generation X, there were 6 different languages recorded by the researcher. The sixth languages were Indonesian, English, Arabic, Javanese, Japanese and Palembangnese. The participant in generation $\mathrm{X}$ and generation $\mathrm{Y}$ tend to use mixed language in their WhatsApp communication.

\subsection{Capital Letters for Emphasis}

In this data, the percentage of generation $\mathrm{X}$ is large which gained $4.7 \%$ for 45 cases, while generation $\mathrm{Y}$ gained only $0.5 \%$ (3 cases). This also shows that generation recently more used capital letters for emphasis during sending a text than generation $\mathrm{Y}$.

1) a. "SEMANGAAAAT....." (Generation $X$ )

b. "FIGHTING...."

c. (Keep spirit!)

2) a. "HBD mbak Shirley..." (Generation Y)

b. "Happy Birthday Shirley...."

c. (Happy birthday Shirley)

From the data above Capital letters were used for emphasis a total of 45 occurrences for Generation $\mathrm{X}$ and 3 occurrences for Generation Y throughout all WhatsApp messages.

\section{CONCLUSIONS}

The study concludes that the Generation X and Generation Y employed various linguistic and discourse features in their WhatsApp Messenger. From the total messages available, there were 4109 messages. In generation $X$ of the total 959 linguistic features produced and 953 cases in discourse features while the generation of $\mathrm{Y}$ total linguistic features produced were 
657 and 575 in discourse items. For the further study, the data taken must be in a large number, various generations and employed gender differences.

\section{ACKNOWLEDGEMENTS}

Special thanks are extended to Dr. Alan McGee from Professional and Continuing Education (PACE) Massey University for proof reading this article.

\section{REFERENCES}

[1] D. Bouhnik and M. Deshen, "WhatsApp Goes to School: Mobile Instant Messaging between Teachers and Students," J. Inf. Technol. Educ. Res., vol. 13, pp. 217-231, 2014.

[2] A.-M. M. Gasaymeh, "University Students' use of Whatsapp and their Perceptions Regarding its Possible Integration into their Education," p. 11, 2017.

[3] M. A. Ahmad and S. M. Tarmudi, "Generational Differences in Satisfaction with E-Learning among Higher Learning Institution Staff,” Procedia - Soc. Behav. Sci., vol. 67, pp. 304-311, Dec. 2012.

[4] "Linguistic_and_Discoursal_Features_of_Te.pdf." .

[5] Y. Q. Yusuf, Y. Natsir, and S. R. Yusra, "(...)/ dont 4get 2 txt me plz! Linguistic and Discoursal Features of Short Message Service by Female Texters," 3L Southeast Asian J. Engl. Lang. Stud., vol. 22, no. 1, pp. 81-96, Mar. 2016.

[6] D. Crystal, Txtng: The Gr8 Db8. OUP Oxford, 2008.

[7] Y. Q. Yusuf, Y. Natsir, and S. R. Yusra, "(...)/ dont 4get 2 txt me plz! Linguistic and Discoursal Features of Short Message Service by Female Texters," 3 L Southeast Asian J. Engl. Lang. Stud., vol. 22, no. 1, pp. 81-96, Mar. 2016.

[8] K. M. Thomas and C. D. McGee, "The Only Thing We Have to Fear is... 120 Characters," TechTrends, vol. 56, no. 1, pp. 19-33, Jan. 2012.

[9] H. Wang and J. Jiang, "On Features of Logistics English from Linguistic Perspective," in 2014 International Conference on Management of e-Commerce and e-Government, Shanghai, China, 2014, pp. 383-387.

[10] Y. Hård af Segerstad, "Language Use in Swedish Mobile Text Messaging," in Mobile Communications, London: Springer-Verlag, 2005, pp. 313-333.

[11] R. Grinter and M. Eldridge, "Wan2tlk?: everyday text messaging," in Proceedings of the conference on Human factors in computing systems - CHI '03, Ft. Lauderdale, Florida, USA, 2003, p. 441.

[12] D. Powell and M. Dixon, "Does SMS text messaging help or harm adults' knowledge of standard spelling?: Does texting help or harm spelling?," J. Comput. Assist. Learn., vol. 27, no. 1, pp. 5866, Feb. 2011.

[13] T. A. Jibril and M. H. Abdullah, "Relevance of Emoticons in Computer-Mediated Communication Contexts: An Overview,” Asian Soc. Sci., vol. 9, no. 4, Mar. 2013.

[14] T. Kroll, L.-M. Braun, and S. Stieglitz, "Accommodated Emoji Usage: Influence of Hierarchy on the Adaption of Pictogram Usage in Instant Messaging," presented at the Australasian Conference on Information Systems, Sydney, 2018.

[15] R. Panckhurst, "A Large SMS Corpus in French: From Design and Collation to Anonymisation, Transcoding and Analysis," Procedia - Soc. Behav. Sci., vol. 95, pp. 96-104, Oct. 2013. 